\title{
FABRICATION OF COMPOSITE COPPER/FLY ASH FOAM WITH EGG YOLK AS FOAMING AGENT
}

\author{
Amir Arifin, Gunawan, Surya Adi Chandra* \\ Department of Mechanical Engineering, Universitas Sriwijaya, Palembang, Indonesia \\ *Corresponding author: amir@unsri.ac.id \\ (Received: 2 October 2020; Accepted: 17 November 2020; Published on-line: 30 November 2020)
}

\begin{abstract}
Copper has been widely in many applications such as heat exchangers due to mechanical and physical properties. In this work, the composite foam was fabricated by powder metallurgy method with fly ash powder and egg yolk as a foaming agent and reinforcement, respectively. Mechanical properties of the specimen were characterize using a compaction test. Moreover, observation of the specimen was conducted using the measurement of shrinkage and porosity. The strength of the specimen was obtained in the range $1: 1,25$ is $0,26 \mathrm{MPa}$ through compaction test. Porosity measurement revealed that maximum and minimum porosities are $88.79 \%$ and $71.53 \%$, respectively. Optical Microscope and Scanning Electron Microscopy observation size of the pores ranging from $21,63 \mu \mathrm{m}$ to $169,7 \mu \mathrm{m}$. Moreover, some crystalline phase was observed using X-Ray Diffraction Test.
\end{abstract}

KEYWORDS: Composite, Copper, Fly Ash, Egg Yolk, Porosity.

\section{INTRODUCTION}

Copper is one of the most used metals for daily life. Copper is considered due to advantageous properties such as good corrosion resistance, good thermal conductivity, and electric conductivity [1]. Commonly, copper is applied to components that required heat and electric transfer components such as heat exchanger and cable, respectively [2]. Moreover, the high corrosion resistance of copper is one reason to be the main alternative material for fluid transfer [3]. The application of heat exchanger has been widely utilized copper as a base material.

The advantages of copper make it interesting to make as metal foam. Another reason copper is widely used because this metal provides better properties as is generally the composite when combined with other materials [4].

Metal foam is a new type of material that is made to make the material have a lower density, better electrical conductivity, better thermal conductivity, and so on [5]. This material has the potential to provide a lightweight structure because the pores make the metal more diffuse while maintaining its properties but making it lighter and more cost-effective. Besides, metal foam is also expected to absorb energy and be able to regulate the rate of heat flow that exists to either hold it or drain it. Metal foam can be made using the Powder Metallurgy method. Metal foam is Also endeavored to be made as much as possible to be recycled and non-toxic to preserve the environment [6].

In this research, copper is used as a matrix, fly ash as reinforce, and egg yolk as a foaming agent. Egg yolk serves to make the specimens porous to be dried with the variation of drying temperature $140^{\circ} \mathrm{C}$ with sintering temperature $800^{\circ} \mathrm{C}$ and heating rate $10^{\circ} \mathrm{C} / \mathrm{min}$, drying 
temperature $160^{\circ} \mathrm{C}$ with sintering temperature $800^{\circ} \mathrm{C}$ and heating rate $10^{\circ} \mathrm{C} / \mathrm{min}$, and drying temperature $180^{\circ} \mathrm{C}$ with sintering temperature $800^{\circ} \mathrm{C}$ and heating rate $6^{\circ} \mathrm{C} / \mathrm{min}, 8^{\circ} \mathrm{C} / \mathrm{min}$, and $10^{\circ} \mathrm{C} / \mathrm{min}$. Several methods have been developed for producing metal foam like the Powder Metallurgy method[7], Entrapped Gas Expansion[6], and Gas Injection[5]. This research using the Powder Metallurgy Method with Copperas Matrix, Fly Ash as Reinforce, and Egg Yolk as a foaming agent. The use of fly ash indicates that this material will be a composite type of material. In the process of making composite copper/fly ash foam, several parameters must be considered, as the variation ratio between copper/fly ash and egg yolk, drying temperature, sintering temperature, and heating rate are the main parameters in finding the most appropriate variation in making composite copper/fly ash foam. Research on making composites made from copper with fly ash as reinforce and egg yolk as foaming agent has not been developed. So we need further analysis, especially in the manufacture of composite foam. The purpose of this research is to make composite copper/fly ash foam with egg yolk as foaming agent and then characterize the material and analyze the effect of variation ratio between copper/fly ash and egg yolk, drying temperature, sintering temperature, and heating rate.

\section{RESULTS AND DISCUSSION}

Before we started the powder metallurgy process, first of all, we observe the copper powder and fly ash with SEM to see the sizes and shape of each material. As for the copper powder, we got the size $<40.23 \mu \mathrm{m}$ and has a dendritic shape that can be seen in Figure 1. Meanwhile, the fly ash has $<29.76 \mu \mathrm{m}$ for the size and spherical shape that can be seen in Figure 2.

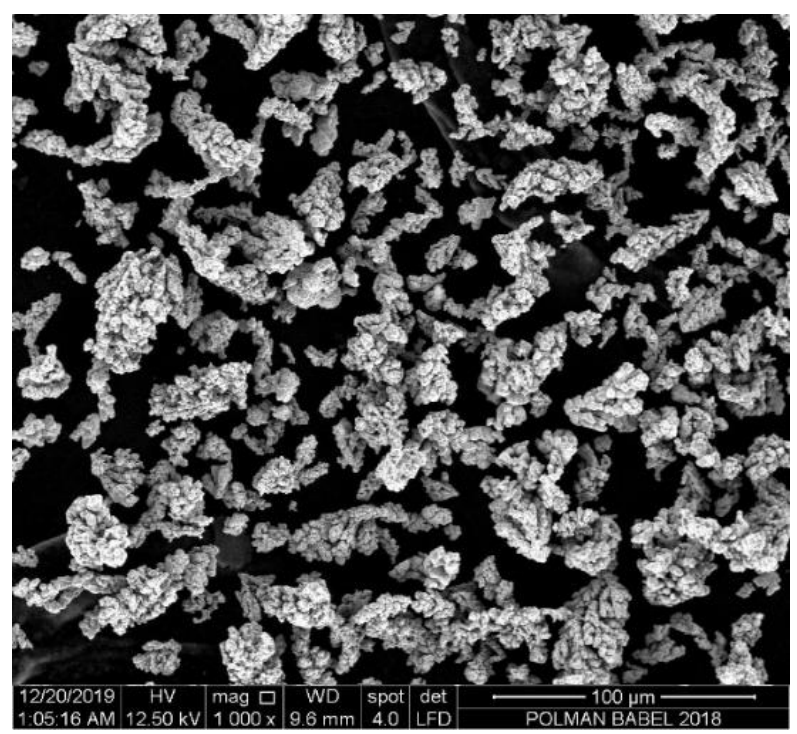

Fig 1. Copper with 1000x magnification 


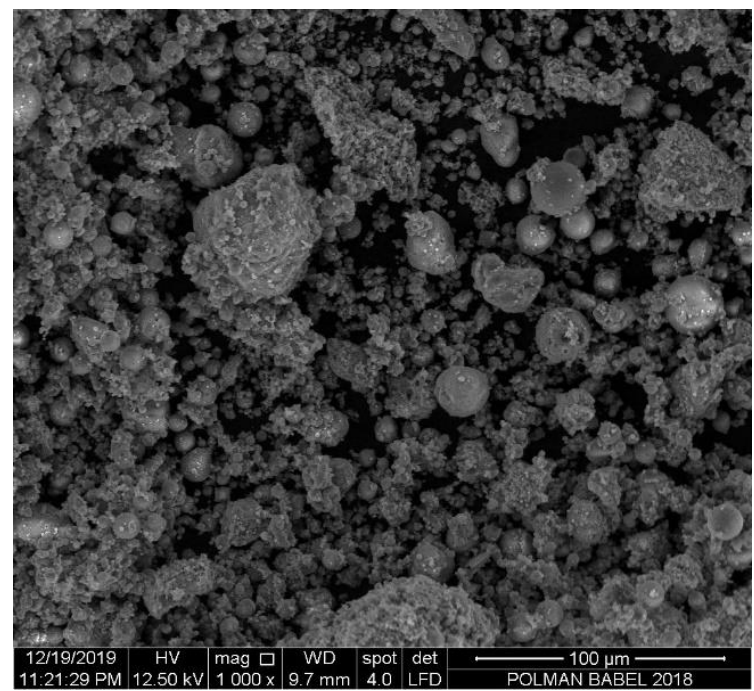

Fig 2. Fly Ash with 1000x Magnification

Composite manufacturing will be carried out using copper powder with $<40.23 \mu \mathrm{m}$ and fly ash $<29.76 \mu \mathrm{m}$ size. With a difference in size that is not too large, it is expected that the composite sample has a small porosity and is easily spread due to the good flow ability of the fly ash [8].

After that began the process of making composite copper/fly ash foam using the powder metallurgy method. After making the composite is complete, the shrinkage measurement is done by comparing the size before and after the sintering is done. Shrinkage measurement results can be seen in Figure 3.

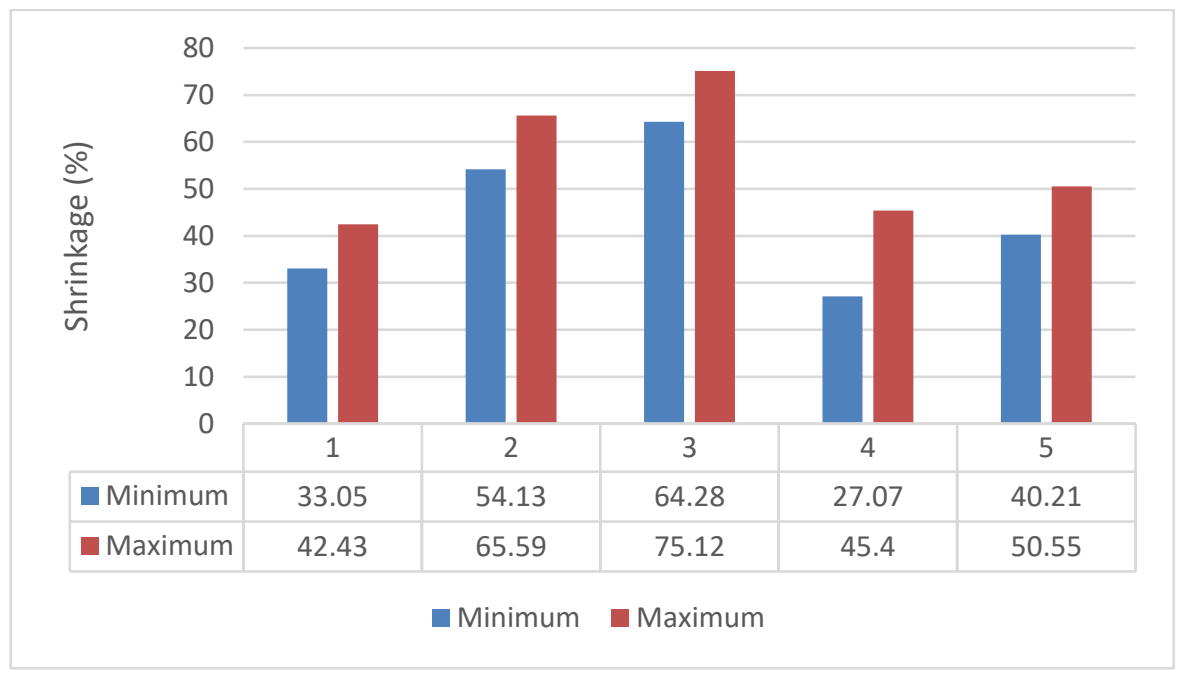

Fig 3. Average shrinkage graph

The difference in the shrinkage percentage from the five sample variations used is due to the difference between copper and fly ash with egg yolk. In the TGA egg yolk test that has been done is known to occur decomposition of water content at temperatures around $100^{\circ} \mathrm{C}$, lipid at temperatures around $100^{\circ} \mathrm{C}-340^{\circ} \mathrm{C}$, and protein at temperatures around $340^{\circ} \mathrm{C}-550^{\circ} \mathrm{C}[9]$. When the sintering starts there will be a decomposition process of water content that produces water vapor which initiates the material to expand slightly before it finally solidifies. Then a decomposition of fat and protein occurs. These three decomposition processes can change the shape of the composite copper/fly ash foam sample to be irregular. It is known from Figure 3 
that there is an increase in shrinkage with an increasing ratio between copper/fly ash with egg yolk.

Furthermore, density testing and measuring the porosity that exists on the composite that has been made. The measurement results can be seen in Figure 4.

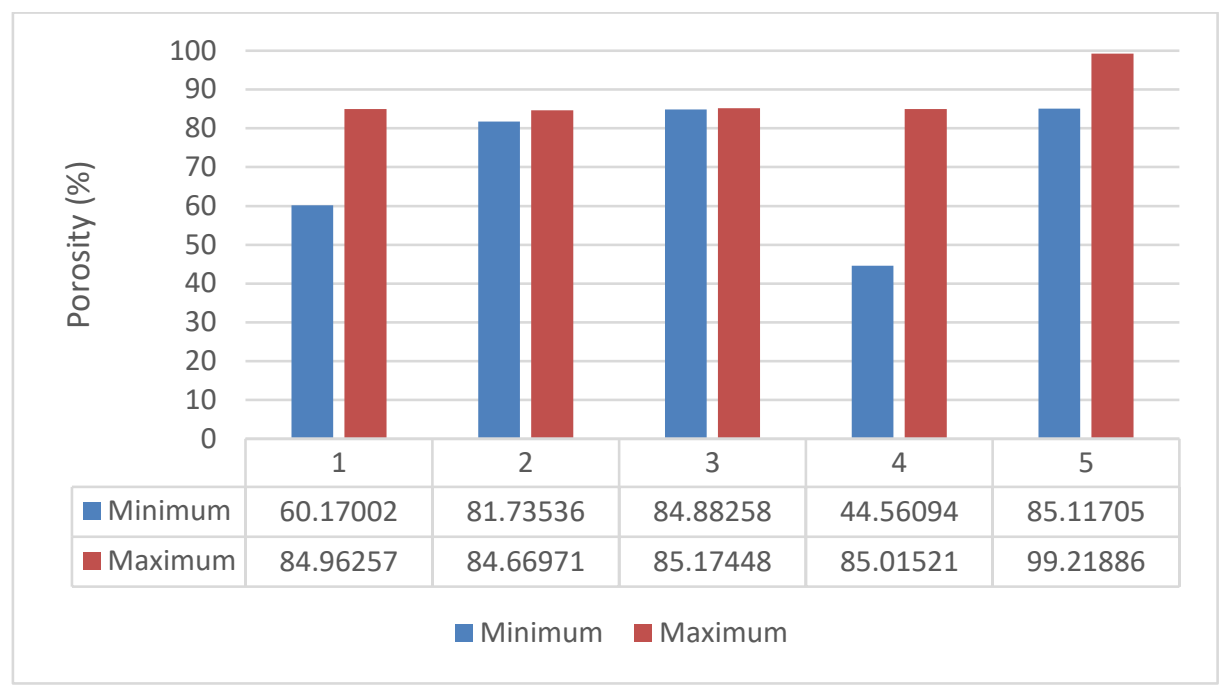

Fig 4. Copper/Fly Ash Composite Foam Porosity Graph

In figure 4 it is known that the average porosity of samples made with copper as a matrix, fly ash as a reinforced, and egg yolk as foaming agent produces varying pores ranging from $70 \%$ to $90 \%$. Variations that produce pores with varying percentages and can be repeated well are a ratio of $1: 1.25$, with a drying temperature of $160^{\circ} \mathrm{C}$, and a heating rate of $10^{\circ} \mathrm{C} / \mathrm{min}$. Also, the density produced is lower than the theoretical density of copper, so the manufacture of porous copper/fly ash composites to reduce its density was successfully made.

After getting the best sample variations through visibility, friability, density test, and porosity measurement, a compressive test was carried out at a ratio of 1:1.25. Regarding the results of compressive tests and calculate porosity that has been done. So, can be made a comparison graph of the average compressive strength of the sample and the porosity of several samples of the test results which can be seen in Figure 5.

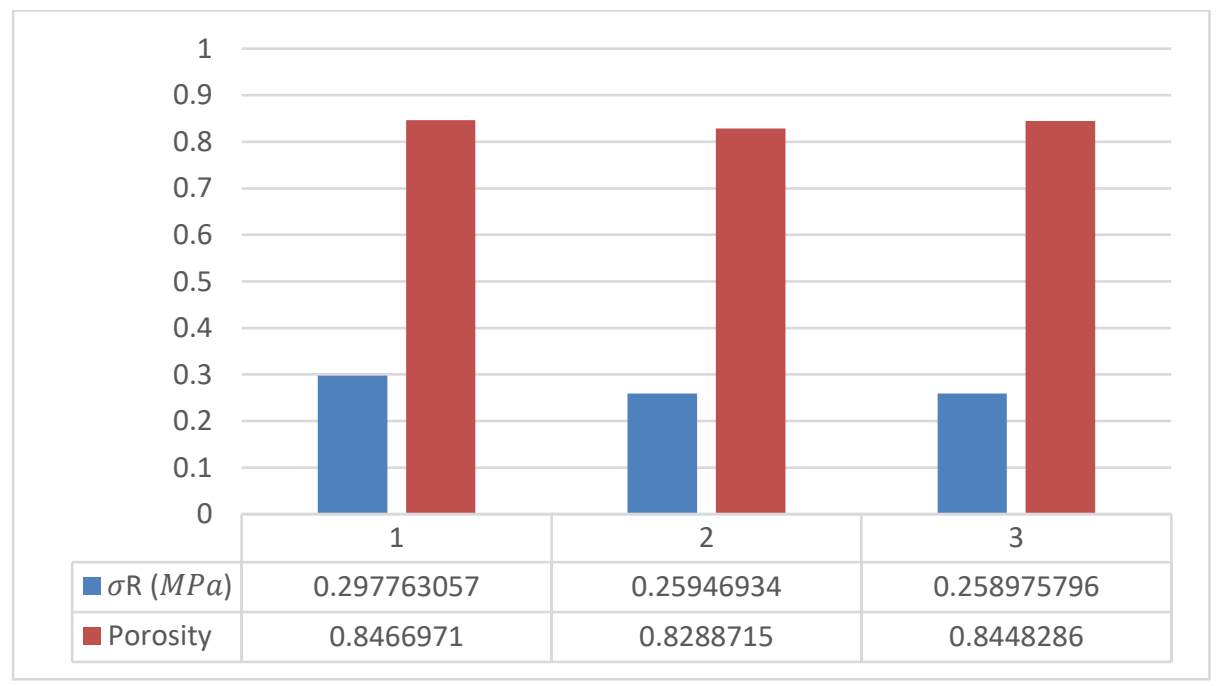

Fig 5. Graph of the relationship between compressive strength with porosity on the sample with variation 1:1.25 
The macrostructure of the composite sample can be seen in Figure 6 and Figure 7 can be seen in the microstructure obtained through observations using Optical Microscopy.

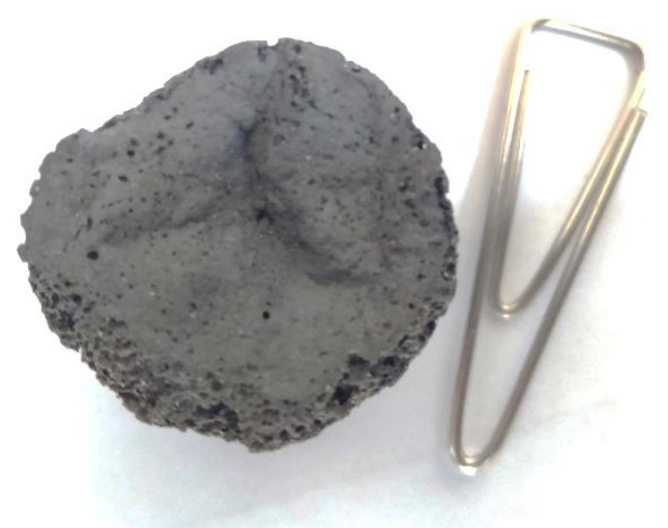

Fig 6. Macrostructure of copper/fly ash composite foam with 1:1.25 variation and 5x Magnification

The visible number of pores formed on the surface of the composite sample that has been made. Pores that are formed are in the form of open cells and plain view, a lot of pores are formed.

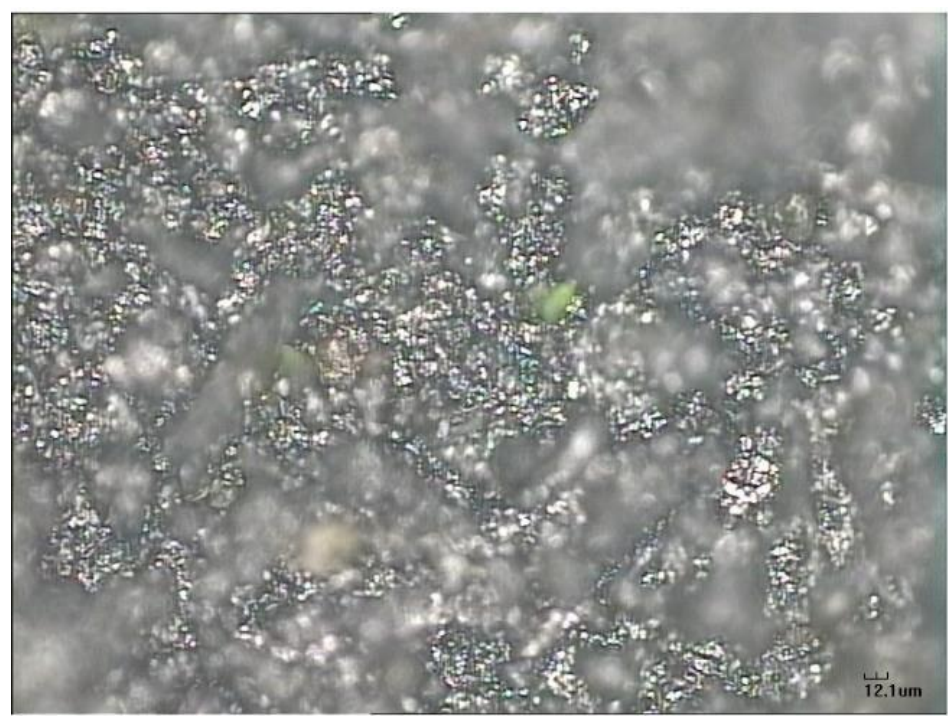

Fig 7. The microstructure of copper/fly ash composite foam with 1:1.25 variation and 200x Magnification

Figure 7 shows white spots attached to the sample. These white spots may come from refractory material which is attached when the sintering process is carried out in the furnace.

After observing the test using Optical Microscopy, further observations were made using the Scanning Electron Microscopy to see the microstructure more clearly because the irregular surface resulted in difficulty obtaining good results on observations using Optical Microscopy as well as to measure the size of the shaft formed. 


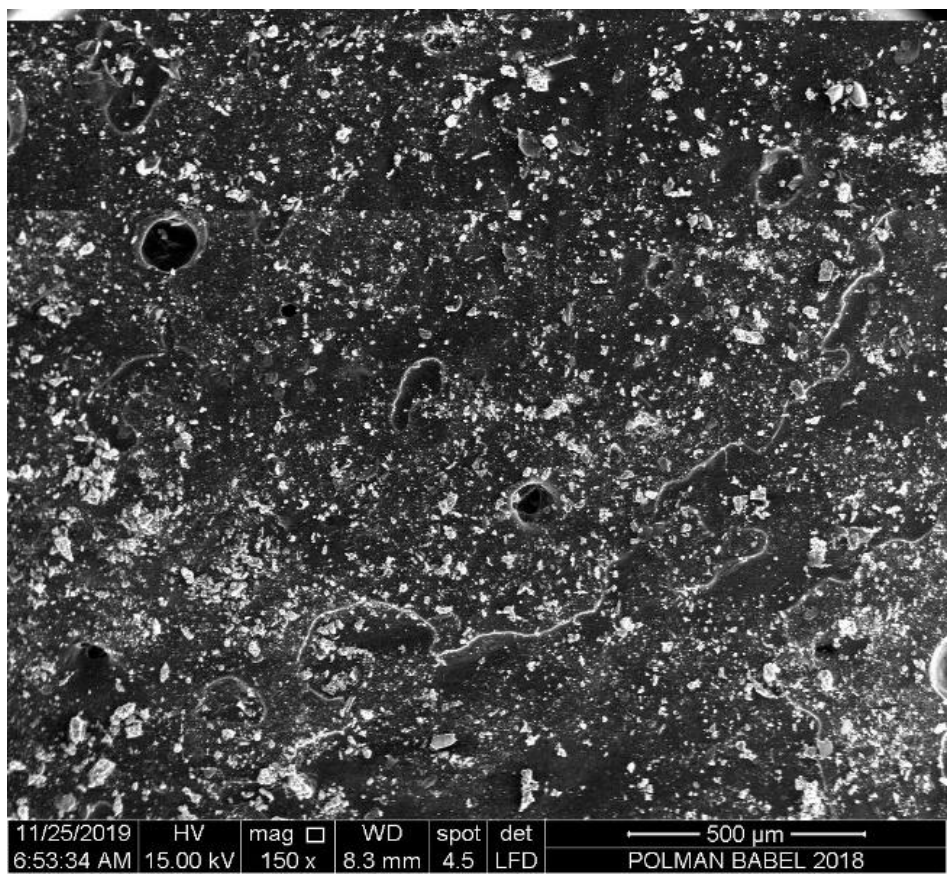

Fig 8. Observation result using SEM on $1^{\text {st }}$ point with $150 x$ Magnification

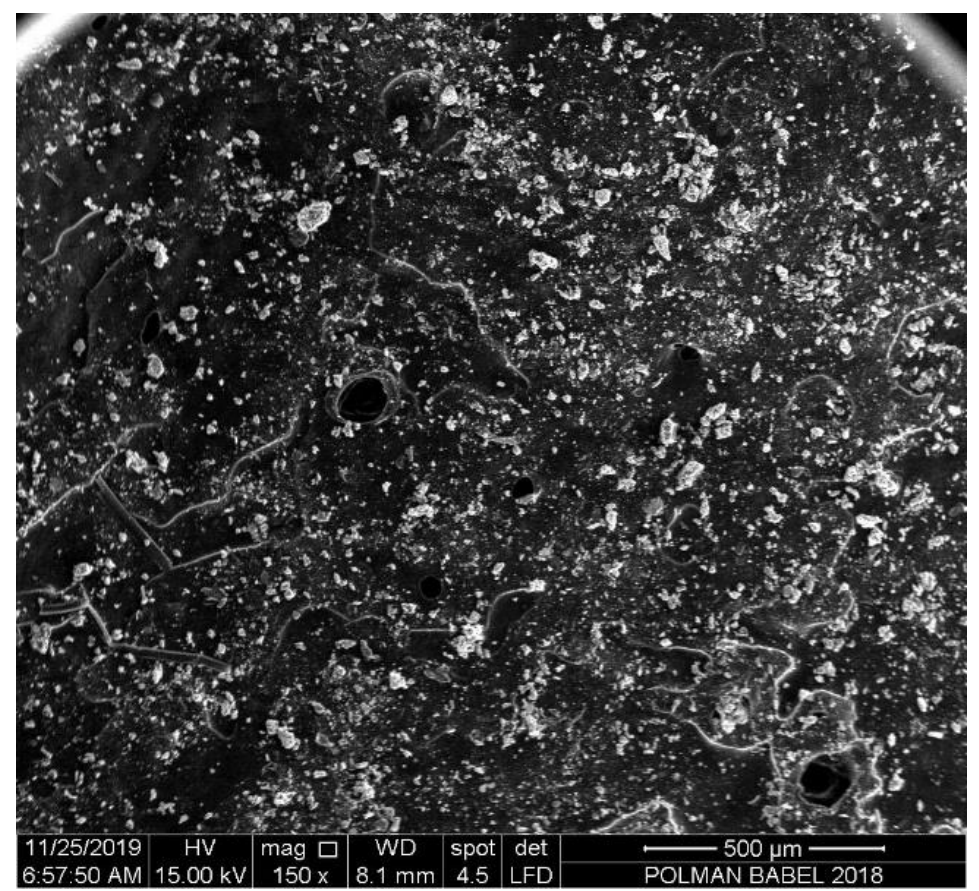

Fig 9. Observation result using SEM on $2^{\text {nd }}$ point with 150x Magnification

From observations at 2 points in Figure 8 and Figure 9 in the same test sample, it can be seen that there are many pores with varying sizes. The pore shape does not appear to have a clear and uniform shape. Pore sizes range from $21.63 \mu \mathrm{m}$ to $169.7 \mu \mathrm{m}$. The results of these SEM observations prove that the egg yolk that forms a pore has formed many open pores with a shape that is almost like a circle although not uniform in size. Then, the SEM results analyzed are samples with a variation of 1:1.25. As it is known that the ratio of copper is more than fly ash with $85 \%$ copper and $15 \%$ fly ash so it is estimated that the white lump in SEM observations made is fly ash and fly ash stick to copper. 
To find out the composition of the content formed in composites that have been made, then XRF testing was carried out on the sample and XRD test on the composite copper/fly ash powder.

Table 1. XRF test result on composite copper/fly ash foam

\begin{tabular}{ccc}
\hline Element & $\%$ & $\pm 2 \sigma$ \\
\hline $\mathrm{Fe}$ & 0,473 & 0,032 \\
$\mathrm{Cu}$ & 99,26 & 0,12 \\
$\mathrm{Zr}$ & 0,035 & 0,014 \\
\hline
\end{tabular}

It can be seen from the table that the content of the constituents other than copper is Fe (Iron) and $\mathrm{Zr}$ (Zirconium). The percentage of all substances that are read is $99.768 \%$. This shows that there are $0.232 \%$ unreadable substances that can be read by XRF test equipment. It is estimated that the unreadable substance is the residue from the organic elements of Egg Yolk or Copper because the $\mathrm{Cu}$ content should indicate $95 \%$.

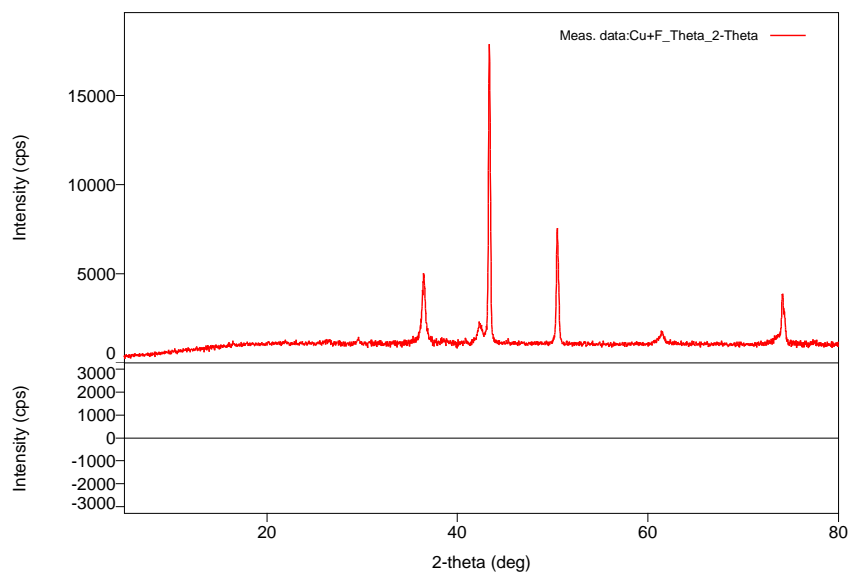

Fig 10. XRD Measurement profile of composite copper/fly ash foam

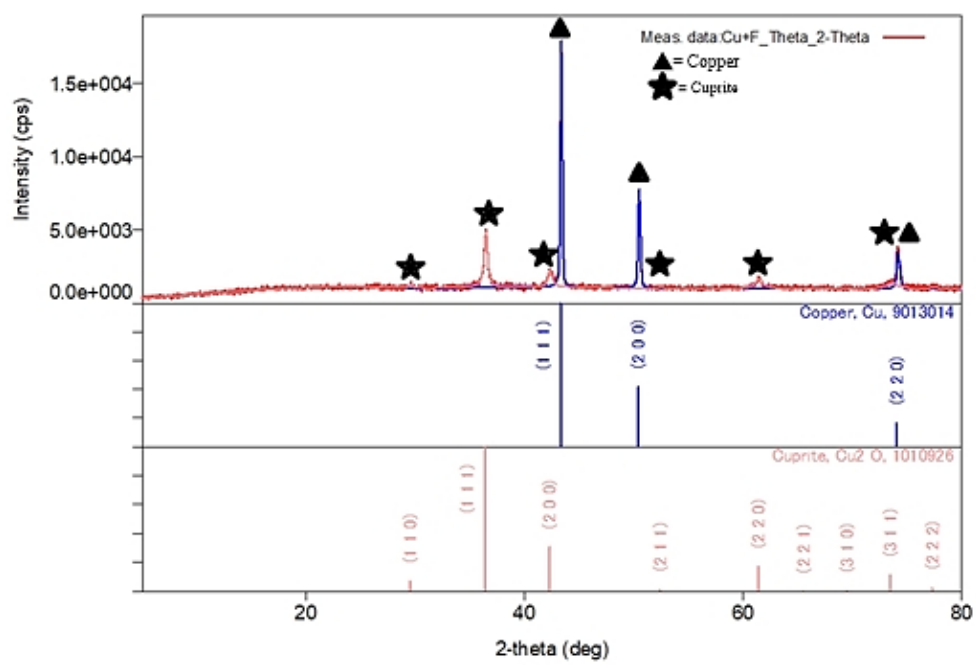

Fig 11. Spectrum pattern of composite copper/fly ash foam

It can be seen that the element formed $\mathrm{CuO}$ (Cuprite) in the composite sample of copper/fly ash was made. This shows the oxidation reaction on copper $(\mathrm{Cu})$. Oxidation reactions are expected to occur when the sintering process is carried out and oxygen enters through cracks 
in the furnace or oxidation may occur in the copper powder when weighing and measuring are carried out before the powder metallurgy process is carried out.

After all tests and observations have been carried out, results are obtained that can be compared with other porous materials that have been made which can be seen in Table 2 .

Table 2. Comparison of Copper Foam that has been made with other porous metals

\begin{tabular}{|c|c|c|c|c|c|}
\hline $\begin{array}{l}\text { Application/Basic } \\
\text { Manufacture }\end{array}$ & $\begin{array}{l}\text { Porosity } \\
(\%)\end{array}$ & $\begin{array}{l}\text { Pore } \\
\text { Per } \\
\text { Inch }\end{array}$ & Pore sizes & $\begin{array}{l}\text { Compressive } \\
\text { strength (Mpa) }\end{array}$ & Reference \\
\hline Heat Sinks & $85-97$ & $\begin{array}{l}20 \text { PPI, } \\
30 \text { PPI }\end{array}$ & I, & - & {$[10]$} \\
\hline $\begin{array}{c}\text { Enhancement of } \\
\text { heat transfer }\end{array}$ & 98 & $\begin{array}{l}20 \text { PPI, } \\
30 \text { PPI }\end{array}$ & $\begin{array}{c}1000 \mathrm{~nm} \\
-50 \mathrm{~nm}\end{array}$ & - & [11] \\
\hline $\begin{array}{c}\text { Electronic } \\
\text { cooling system }\end{array}$ & 97 & - & $\begin{array}{l}100 \mu m- \\
25 \mu m\end{array}$ & - & [12] \\
\hline $\begin{array}{c}\text { Porous Alumina } \\
\text { EY }\end{array}$ & $46-52$ & - & - & $0,1-6,4$ & [13] \\
\hline $\begin{array}{c}\text { Porous Ceramic } \\
\text { EY }\end{array}$ & $40-71$ & - & $\begin{array}{l}200 \mu m- \\
1000 \mu m\end{array}$ & $1,1-5,7$ & [9] \\
\hline CCF $1: 1,25$ & $81,73-84,66$ & - & $\begin{array}{c}21,63 \mu \mathrm{m}- \\
169,7 \mu \mathrm{m}\end{array}$ & $0,25-0,29$ & $\begin{array}{l}\text { Current } \\
\text { study }\end{array}$ \\
\hline
\end{tabular}

\section{CONCLUSION}

In summary Copper/fly ash composite foam with egg yolk as the foaming agent was successfully fabricated. From the progress, we got the best variation which is 1:1.25 variation. Water was used as a binder for the copper/fly ash composite. Moreover, the mechanical strength result for this variation is $0.27 \mathrm{MPa}$. The Shrinkage result average that happened increases with the addition of egg yolk as a foaming agent. The density of composite copper/fly ash can be made lighter than copper density in general. The smaller the density obtained, the higher the porosity. Based on observations of macro and microstructures, the pores produced in composite copper/fly ash foam are generally almost spherical in shape and open-cell type with pore sizes ranging from $21.63 \mu \mathrm{m}$ to $169.7 \mu \mathrm{m}$. In the XRD test, it was found that the size of the crystalline obtained was $0,58 \mathrm{~nm}$ and in the XRF test performed on composite copper/fly ash foam samples, 3 types of substances were read, namely $\mathrm{Cu}$ of $99.26 \%, \mathrm{Zr}$ of $0.035 \% \mathrm{~m}$, and $\mathrm{Fe}$ of $0.0473 \%$. Unreadable substances may be residual organic elements or errors of the tool itself.

\section{ACKNOWLEDGEMENT}

Thank you to Universitas Sriwijaya for supporting this research.

\section{REFERENCES}

[1] B. Ertu, Sintering Applications. Croatia: Intech, 2013.

[2] B. F. Topin, J. Bonnet, B. Madani, and L. Tadrist, "Experimental Analysis of Multiphase Flow in Metallic foam : Flow Laws, Heat Transfer and Convective Boiling **," no. 9, pp. 890-899, 2006.

[3] D. E. Tyler and W. T. Black, ASM Handbook Volume 2 Properties and Selection: Nonferrous Alloys and Special-Purpose Materials. ASM International, 1990.

[4] K. J. A. Kundig, Copper and Copper Alloys. New Jersey: Randolph, 2002. 
[5] J. Banhart, Manufacture, characterisation and application of cellular metals and metal foams, vol. 46. Bremen: Frauhofer-Institure for Manufactureing and Advanced Materials, 2001.

[6] M. F. Ashby, A. G. Evans, N. A. Fleck, L. J. Gibson, J. W. Hutchinson, and H. N. G. Wadley, Metal Foams : A Design Guide. United States of America: Butterworth-Heinemann, 2007.

[7] J. Baumeister, J. Banhart, and M. Weber, "Aluminium foams for transport industry," vol. 18, pp. 217-220, 1998.

[8] L. T. Nji, "Fly Ash : Overview - Lauw Tjun Nji," 2015. .

[9] A. Fadli and I. Sopyan, "Porous ceramics with controllable properties prepared by protein foaming-consolidation method," pp. 195-203, 2011.

[10] J. Wang, H. Kong, Y. Xu, and J. Wu, "Experimental investigation of heat transfer and flow characteristics in finned copper foam heat sinks subjected to jet impingement cooling," Applied Energy, vol. 241, no. November 2018, pp. 433-443, 2019.

[11] Z. Rao, Y. Wen, and C. Liu, "Enhancement of heat transfer of microcapsulated particles using copper particles and copper foam," Particuology, 2018.

[12] T.- Rehman, H. Muhammad, A. Saieed, W. Pao, and M. Ali, "International Journal of Heat and Mass Transfer Copper foam / PCMs based heat sinks : An experimental study for electronic cooling systems," International Journal of Heat and Mass Transfer, vol. 127, pp. 381-393, 2018.

[13] I. Sopyan, A. Fadli, and M. Mel, "Porous alumina - hydroxyapatite composites through protein foaming - consolidation method," Journal of the Mechanical Behavior of Biomedical Materials, vol. 8, pp. 86-98, 2012. 